\title{
Cinegeo
}

International Journal of Environment and Geoinformatics (IJEGEO) is an international, multidisciplinary, peer reviewed, open access journal.

\section{Pre-Historical Submerged Settlements in the Sea of Marmara Coasts}

\section{Günay DÖNMEZ, Hakan KAYA}

\author{
Chief in Editor \\ Prof. Dr. Cem Gazioğlu \\ Co-Editors \\ Prof. Dr. Dursun Zafer Şeker, Prof. Dr. Şinasi Kaya, \\ Prof. Dr. Ayşegül Tanık and Assist. Prof. Dr. Volkan Demir
}

Editorial Committee (December 2020)

Assos. Prof. Dr. Abdullah Aksu (TR), Assit. Prof. Dr. Uğur Algancı (TR), Prof. Dr. Bedri Alpar (TR), Prof. Dr. Levent Bat (TR), Prof. Dr. Paul Bates (UK), İrşad Bayırhan (TR), Prof. Dr. Bülent Bayram (TR), Prof. Dr. Luis M. Botana (ES), Prof. Dr. Nuray Çağlar (TR), Prof. Dr. Sukanta Dash (IN), Dr. Soofia T. Elias (UK), Prof. Dr. A. Evren Erginal (TR), Assoc. Prof. Dr. Cüneyt Erenoğlu (TR), Dr. Dieter Fritsch (DE), Prof. Dr. Çiğdem Göksel (TR), Prof.Dr. Lena Halounova (CZ), Prof. Dr. Manik Kalubarme (IN), Dr. Hakan Kaya (TR), Assist. Prof. Dr. Serkan Kükrer (TR), Assoc. Prof. Dr. Maged Marghany (MY), Prof. Dr. Michael Meadows (ZA), Prof. Dr. Nebiye Musaoğlu (TR), Prof. Dr. Masafumi Nakagawa (JP), Prof. Dr. Hasan Özdemir (TR), Prof. Dr. Chryssy Potsiou (GR), Prof. Dr. Erol Sarı (TR), Prof. Dr. Maria Paradiso (IT), Prof. Dr. Petros Patias (GR), Prof. Dr. Elif Sertel (TR), Prof. Dr. Nüket Sivri (TR), Prof. Dr. Füsun Balık Şanlı (TR), Prof. Dr. Uğur Şanlı (TR), Duygu Ülker (TR), Prof. Dr. Seyfettin Taş (TR), Assoc. Prof. Dr. Ömer Suat Taşkın (US), Assist. Prof. Dr. Tuba Ünsal (US), Dr. İnese Varna (LV), Dr. Petra Visser (NL), Prof. Dr. Selma Ünlü (TR), Prof. Dr. Murat Yakar (TR), Assit. Prof. Dr. Sibel Zeki (TR)

Abstracting and Indexing: TR DIZIN, DOAJ, Index Copernicus, OAJI, Scientific Indexing Services, International Scientific Indexing, Journal Factor, Google Scholar, Ulrich's Periodicals Directory, WorldCat, DRJI, ResearchBib, SOBIAD 


\title{
Review Article
}

\section{Pre-Historical Submerged Settlements in the Sea of Marmara Coasts}

\author{
Günay Dönmez $^{1}$ (D) Hakan Kaya ${ }^{2}$ (D) \\ ${ }^{1}$ Akdeniz University, Mediterranean Civilizations Research Institute \\ ${ }^{2}$ Istanbul Universiy, Institute of Marine Sceinces and Management, Department of Marine Environment (Lecturer)
}

E-mail gunayydonmez@gmail.com

Received 15 Fenb 2020

Accepted 22 Sept. 2020

How to cite: Dönmez and Kaya (2020). Pre-Historical Submerged Settlements in the Sea of Marmara Coasts, International Journal of

Environment and Geoinformatics (IJEGEO), 7(3): 335-346. DOI: 10.30897/ijegeo.788955

\begin{abstract}
Parallel to the development of underwater archeology, sunken cities have been discovered in many parts of the world. These discovered settlements provide us not only with many archaeological data, but also many scientific data such as geological, geomorphological, climatological, oceanography. Thanks to these data, besides the information about past lives, changes in sea and lake levels have shed light on many unknowns such as the reasons for these changes, floods, drought, earthquakes and volcanic activities in the past. In this context, the archaeological artifacts and structures obtained from the Marmara Sea and its surroundings, Istanbul - Selimpaşa Mound, Istanbul - Fenerbahçe Bay, Çanakkale - Işıldak Tepealtı Mound, Marmaray / Yenikapı Excavations, Avşa Island Archeological Underwater Studies were examined. In addition to this examination, the geographical locations of the artifacts in these settlements and the geoarchaeological characteristics of the area where they are located are also examined. In this way, not only the geoarchaeological features of the study area were revealed, but also the environmental conditions and sea level changes were tried to shed light. The settlements mentioned in our study provided important data on sea level changes. In the light of archaeological, geoarchaeological and climatological data, a new evaluation has been made by taking into account the other views on current sea level changes.
\end{abstract}

Keywords: Geoarchaeology, Coast, Pre-historical, Underwater

\section{Introduction}

Coastal areas are natural environments where land, water and air interact with each other, shaped by the influence of internal and external forces. Geological, geomorphological, hydrological and meteorological processes come to the force in shaping a coastline. Level changes in the shoreline affect the placement process has occurred most Holocene Period (Kayan, 1997). It has been seen that the changes in coastal areas are mostly due to the Holocene Period water rises depending on climatic changes. Rising water levels with the temperature increase play a crucial role on changing coasts. Besides, many factors such as earthquakes, erosions, streams and alluvium fillings brought by the streams have also been effective in changing the coastline of Anatolia (Jordan and Maschner, 2000; Kayan, 1997; Dumankaya, 2015).

The sea level, which was low at the beginning of the Holocene period, has gone up both generally and regionally in the last 10-12 thousand years. These rises were of great importance for the human communities settled in the coastal areas, and small-scale sea level changes and differences in coastal geomorphology occurred over the centuries have been influential in the lifestyles of coastal cultures (Kayan, 2020). In this process, many coastal areas were flooded due to the rising water level in the Aegean and Adriatic seas (Van
Andel and Shackleton, 1982; Erol, 1979). A similar process had taken place in the Sea of Marmara and the waters of the Aegean Sea had turned Marmara from a freshwater lake into a sea around $6000 \mathrm{BC}$ through the Dardanelles Strait. In this way, the large planes in the Marmara Region were quickly submerged (Ardel, 1960; Kunter, 1973; Öniz et al., 2015) (Fig.1). The reason for these rises is shown as melting of glaciers together with the calescence, tectonic movements and increasing precipitation. During this period, sea levels appeared to rise, while there was a decrease in the water levels and an increase in salinity rates of some lakes in the inland areas (Burroughs, 2005). These water level changes have also greatly affected the Marmara Sea and its surroundings.

\section{Methodology}

In order to analyze the sea level changes in the Marmara Sea, five archaeological sites in the field have been studied so far. The work was carried out in five stages: first, the field study was carried out. Subsequently, extensive survey was carried out to determine the archaeological material, ancient sources were researched, the environment was examined geomorphological, geological, climatological and underwater scan sonar was researched. 


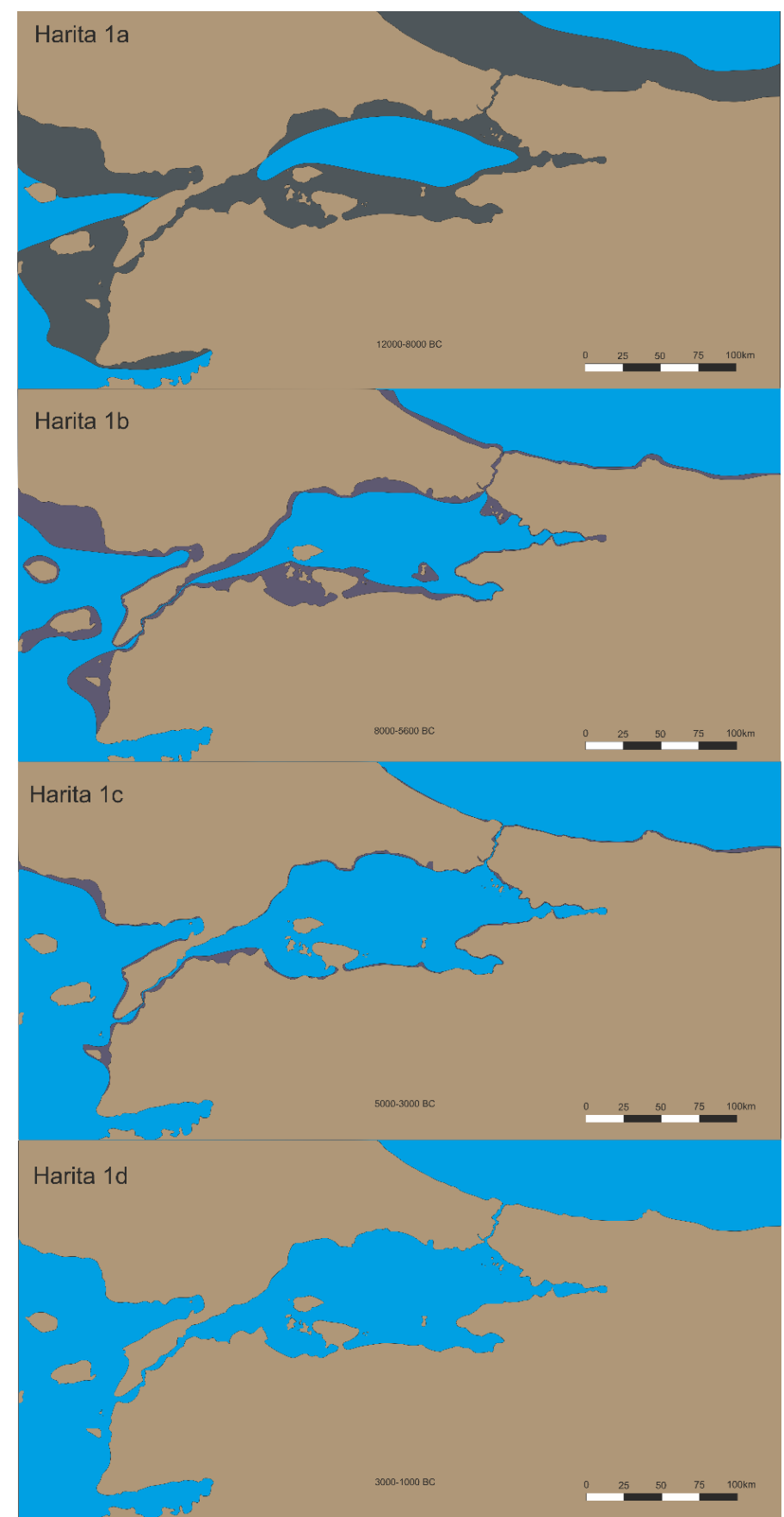

Fig.1: Sea level changes started with Holocene Period on Marmara Sea (Özdoğan, 2011).

\section{Istanbul - Selimpaşa Mound}

Selimpaşa Mound, located within the borders of Silivri district in the Thrace part of Istanbul, is 55 kilometres away from the center of Istanbul. The mound shows itself in the form of an elevation located in the west of the point, where Kavaklidere comes from the north and reaches the Sea of Marmara. The beach lying in front of the mound was formed by the alluviums brought by Kavaklidere and Kocadere, which also empties into the Sea of Marmara at 800 meters east. The mound remains as the last big mound in Thracian part of the west of Istanbul. Within the scope of the Istanbul Prehistoric surface studies conducted under the Leadership of Assoc. Prof. Dr. Ş. Aydıngün, studies on sea and river in Selimpaşa have been carried out by a team including Assoc. Dr. H. Öniz as well. These studies have shown that the traces of settlements of Selimpaşa Mound dating back to the Early Bronze Age remain below sea level. As a result of the georadar studies, anomalies containing sand traces and then cultural soil traces 2 meters below the mound were observed. Researches that were conducted in Küçükçekmece along with Marmaray -Yenikap1 excavations in Istanbul have shown that the sea level has changed several times. It is understood by these studies that the Chalcolithic and Neolithic settlements that should have been on the Marmara shores are a few meters below sea level (Aydıngün et al., 2014) (Fig. 2). 

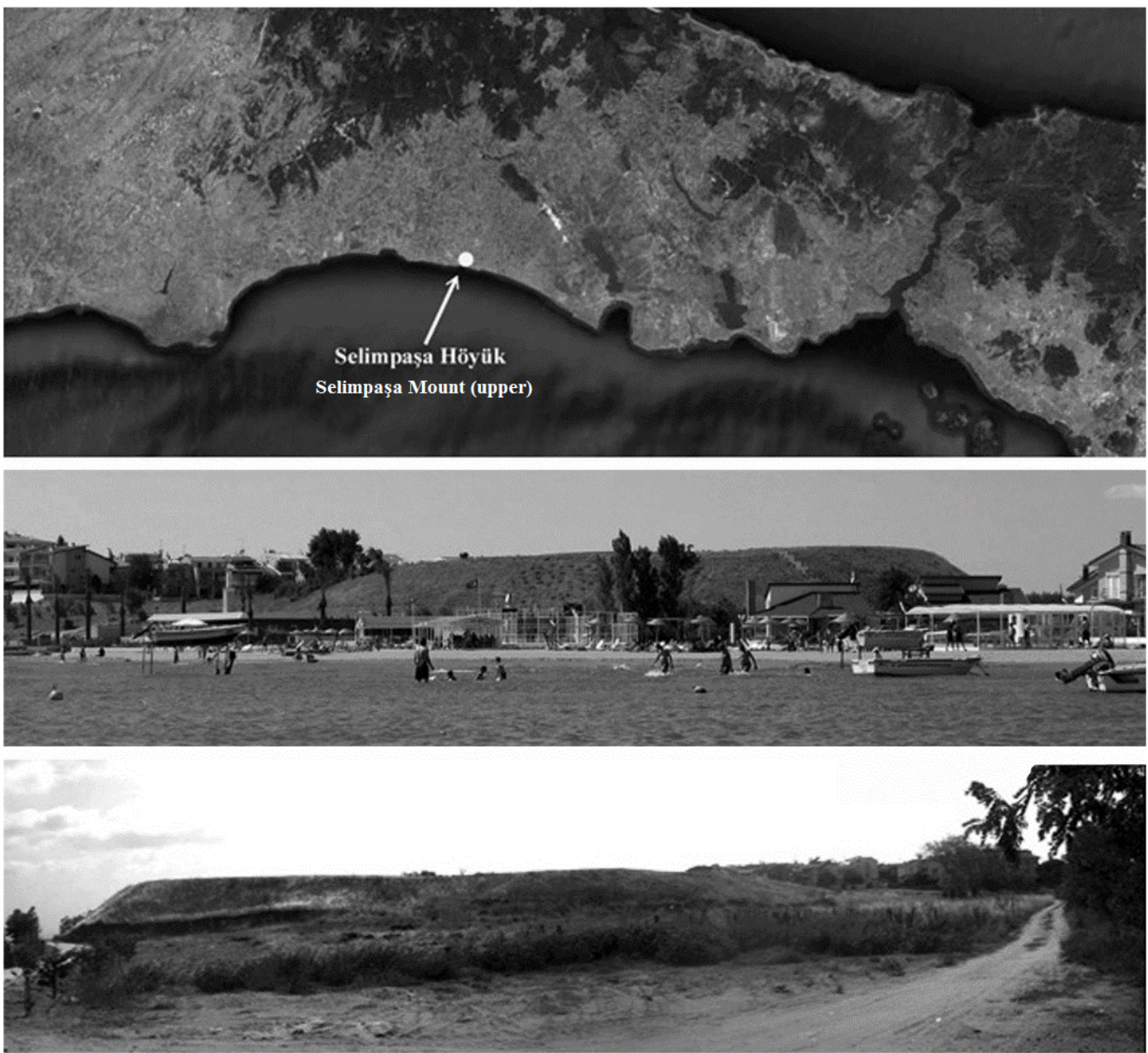

Fig. 2: Selimpaşa Mount (Upper) and view of mount (Aydıngün et al., 2014: 47-55).
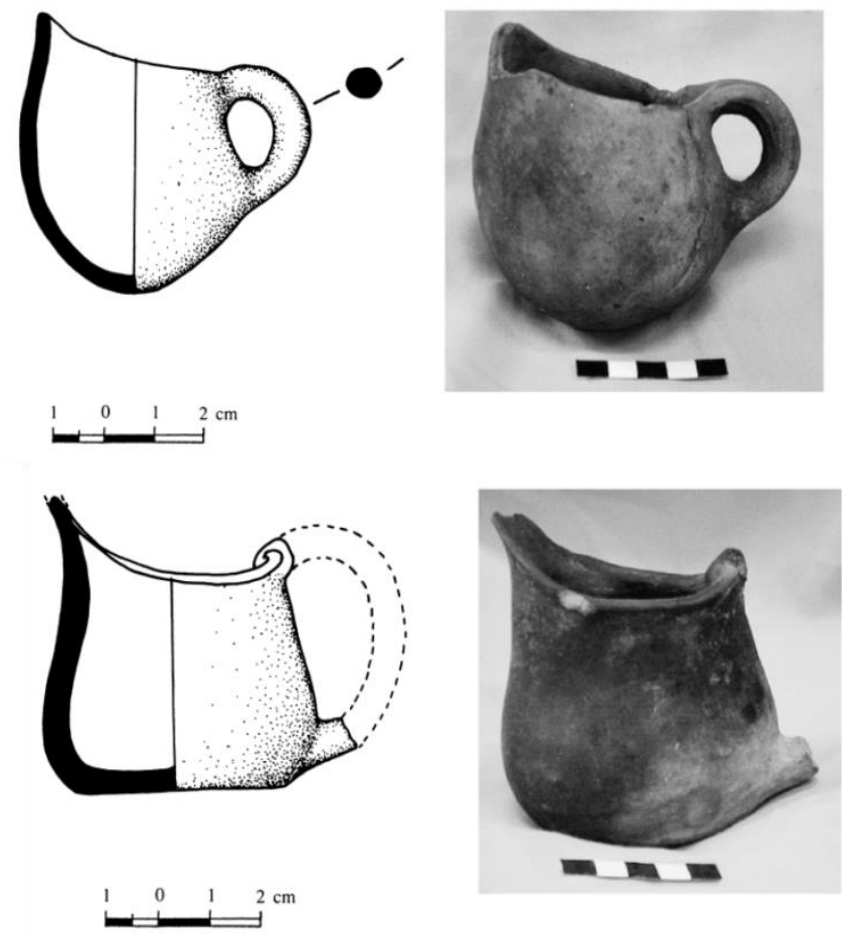

Fig. 3: (Dönmez, 2006, Fig. 3b). Cups found in Fenerbahçe Yatch Harbour. Has dark grey, non-glossy polished, dated in Early Bronze Age II - III (Dönmez, 2006 Fig. 3b). 


\section{Istanbul - Fenerbahçe Yatch Harbour}

Two dippers and two pitchers have been found during the riverbed studies of Kurbağalı Dere Creek in Fenerbahçe Yatch Harbour at the Kalamış Bay on the Anatolian side of Istanbul. Afterwards, underwater researches were carried out in the region, but no sufficient results were achieved due to the limited visibility. During these works, some architectural remains that are considered to be walls have been found and the period to which they belong has not been fully established yet. The ceramics found are dated to the Early Bronze Age II- III. Although they have similarities with Yortan and Thrace cultures, it has been considered that they are the pots of local production (Dönmez, 2006: 245-246.) (Fig. 3).

\section{Çanakkale- Işıldak Tepealtı Mound}

Within the scope of the surface studies conducted by Prof. Dr. Rüstem Aslan about the Prehistoric Period of Bozköy-Hanaytepe and Its Surroundings, some examinations have been made on the Iş1ldak Tepealtı Mound. As a result of these studies, it is thought that the mound was built on the bedrock on the sea shore and it was then covered with landfill came from higher places due to landslide and earthquake occurred in later periods (Aslan, 2011:7). In the first investigations on the remains, it has been observed that the ceramics in the lower layers date back to the Middle Chalcolithic Period. On the other hand, the remains in the upper levels date back to the Late Chalcolithic Period. The mound that is seafront has shown a profile of $40 \mathrm{~m}$ length and $7 \mathrm{~m}$ height. It has been seen that the mound, which dates back to the Chalcolithic Period, is mostly submerged. This situation was documented once again in the master thesis study carried out by Mehmet Can Üstünel in 2018. With the Holocene Period, waters of the Dardanelles started to rise around $6000 \mathrm{BC}$. As a result, it is considered that the majority of the mound is flooded (Fig. 4a, b).

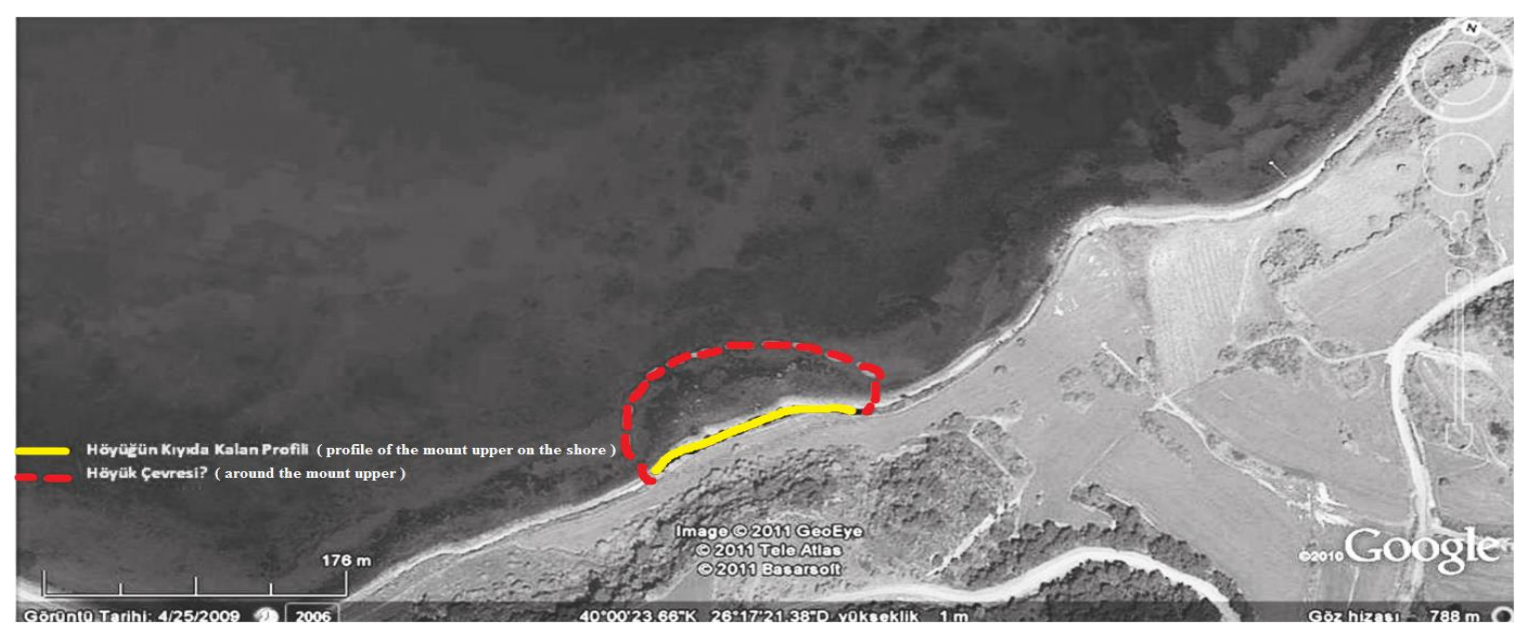

Fig. 4a: Işıldak Tepealtı Mount upper view (Aslan, 2012).

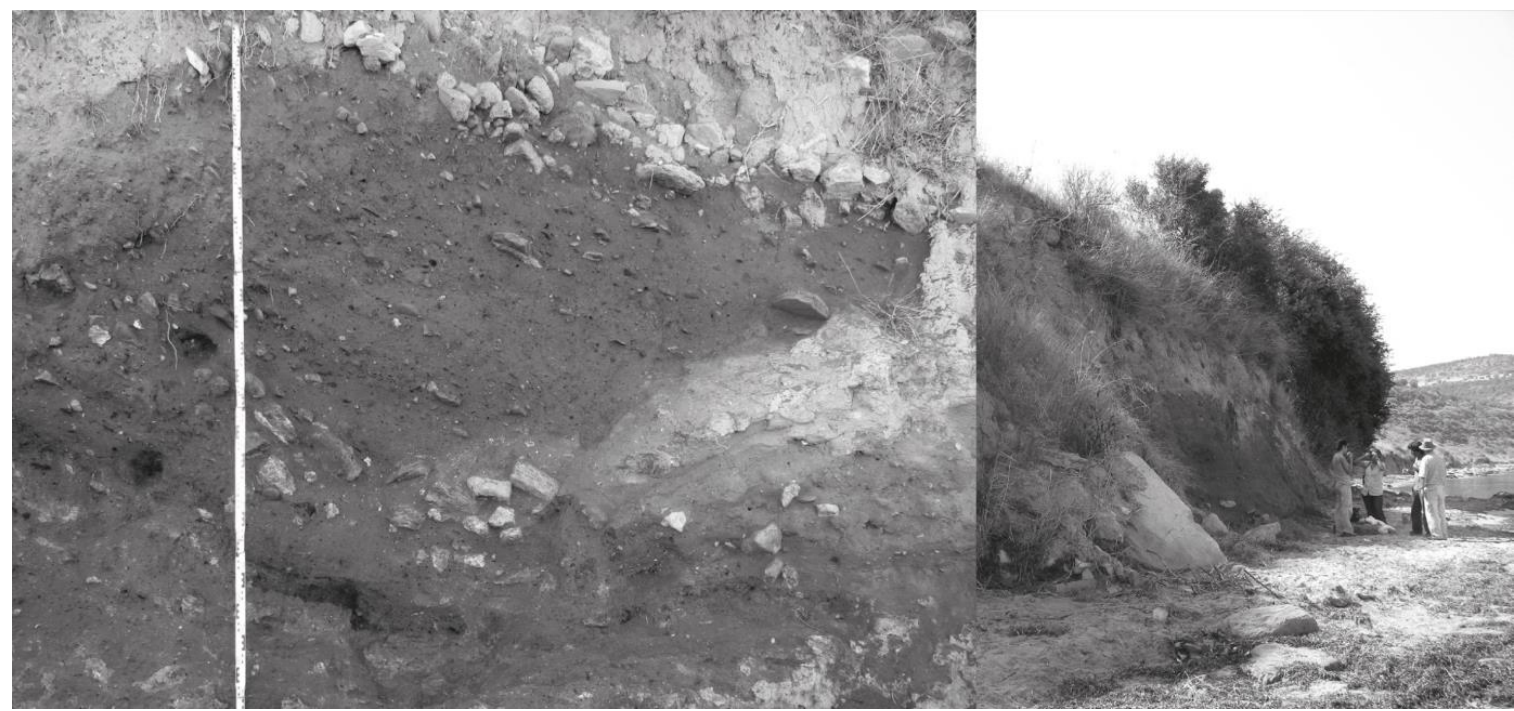

Fig. 4b: Iş1ldak Tepealtı Mount plates (Left), mounts general view (Right) (Aslan, 2012).

\section{Marmaray / Yenikapı Excavations}

Byzantine Theodosian Port was unearthed during the Metro excavations carried out within the Marmaray Project connecting Europe and Asia under the Bosphorus. 34 Byzantine wrecks, Classical and Archaic remains from Hellenistic, Roman, Ottoman times that can be dated back to a period covering the 5 th and 11 th centuries have been found (Kocabaş, 2008) in the rescue excavations carried out by experts from Istanbul Archeology Museum and teams led by Cemal Pulak and 
Ufuk Kocabaş. During these excavations, a settlement dating back to the Neolithic Period has been found (Kiziltan, 2008; Perincek, 2008; Algan et al., 2011).

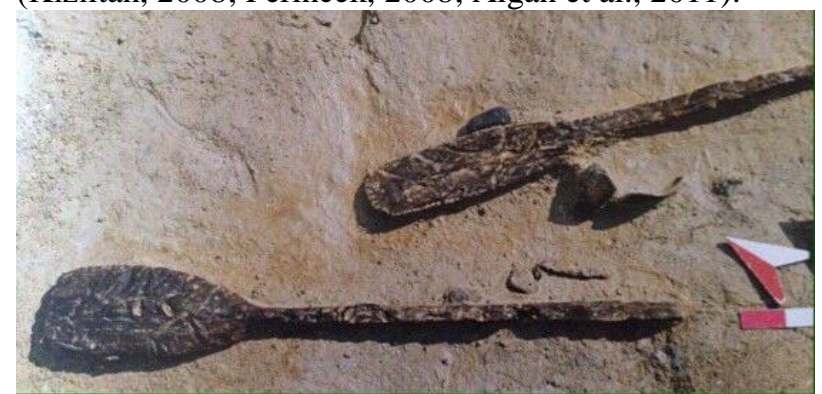

Fig. 5: Wooden paddles from Neolitic Period (Kızıltan, 2008, fig. 19)

The figurines, tombs and architectural elements from the first settlers of Istanbul are dated to the Neolithic Period, based on the similar found in Yarimburgaz Cave and Fikirtepe excavations. And also it was understood that the animals such as sheep, goats and pigs were raised here from their bone samples found in the settlement in question. Additionally, there was a good level of agriculture based on the archaeobotanical researches made on the wheat samples. Besides these various finds such as obsidian and wooden canoe paddles from the period are also seen here (Fig. 5).

Furthermore 2080 footprints belonging to this period is reached which dated back to 8000 years when the

Marmara Sea was a large lake, and it was understood that the footprints were covered with mud and natural factors are helped for preserving them (Pekin 2007).

\section{Avşa Island Archaeological Underwater Studies}

Avşa Island, located within the borders of Marmara Region as a part of Balıkesir province, is located in the southwest of the Sea of Marmara and is one of the islands forming the archipelago called Marmara Islands (Fig.6,7). Written information about the first indigenous people of the island can be accessed from geographer Strabon and historian Plinius. Tools made of flint, obsidian, bone, etc., loom weights, figures and stone axes located in Avsa beaches in recent years has shown that the settlements on the island date back to much older periods.

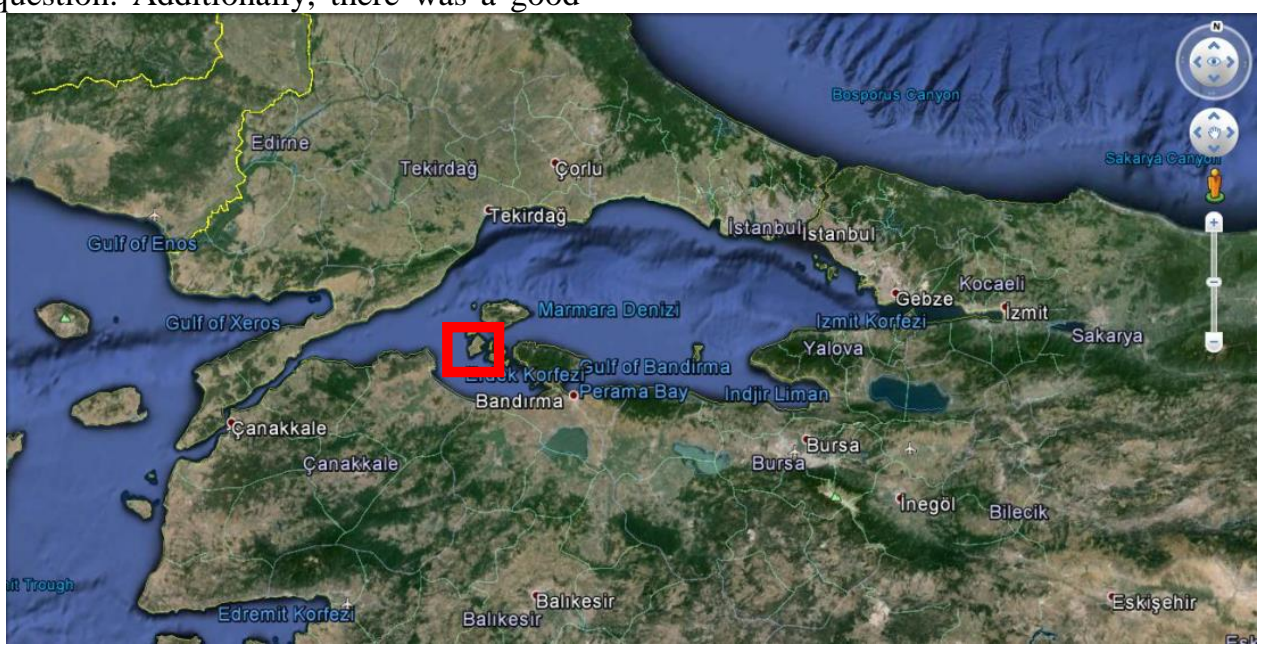

Fig. 6: Marmara Region and Marmara Islands (Google Earth, 2020)

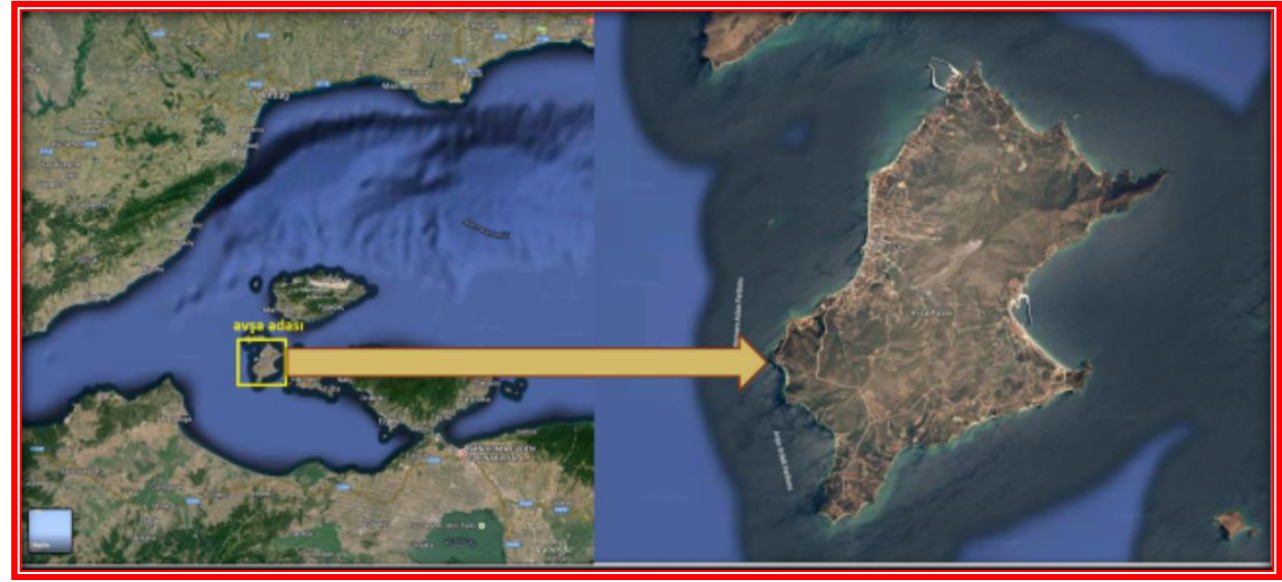

Fig. 7: Avşa Island (Google Earth, 2020)

The first studies in the region were carried out by Prof. Dr. Mehmet Özdoğan in 1993 (Özdoğan, 2003). In 1994, the residential area was also examined by Prof. Dr. Nergis Günsenin (Fig. 8) (Günsenin, 1995). Underwater archaeology studies were carried out on the mound as part of the master thesis project by the author with the permission of the Ministry of Culture and Tourism in 2015. The ruins can be easily seen from the shore at a depth of $1.50-2.00 \mathrm{~m}$. In these studies, which were carried out on Avşa Island, Neolithic, Chalcolithic and intensely Bronze and cube grave samples belonging to the Bronze Age have been seen in 
the submerged part of the mound (Fig. 9). In addition to this, various ceramic samples and remains dating back to a period between the Hellenistic Period and the end of the Late Antiquity have been identified. This indicates that the island remained as a residential area without any interruption since the Prehistoric Period.

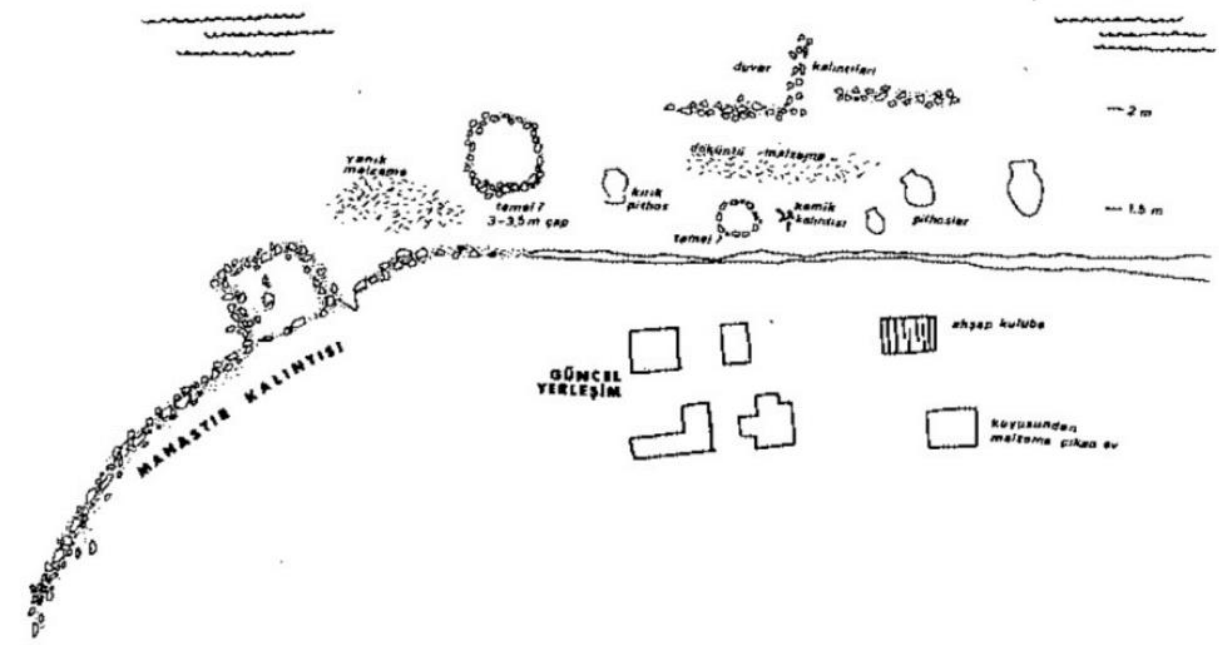

Fig. 8: Sketch of Avşa Island Monastery mount possible remainings and shoreline by Prof. Dr. Nergis Günsenin. (Günsenin, 1995).

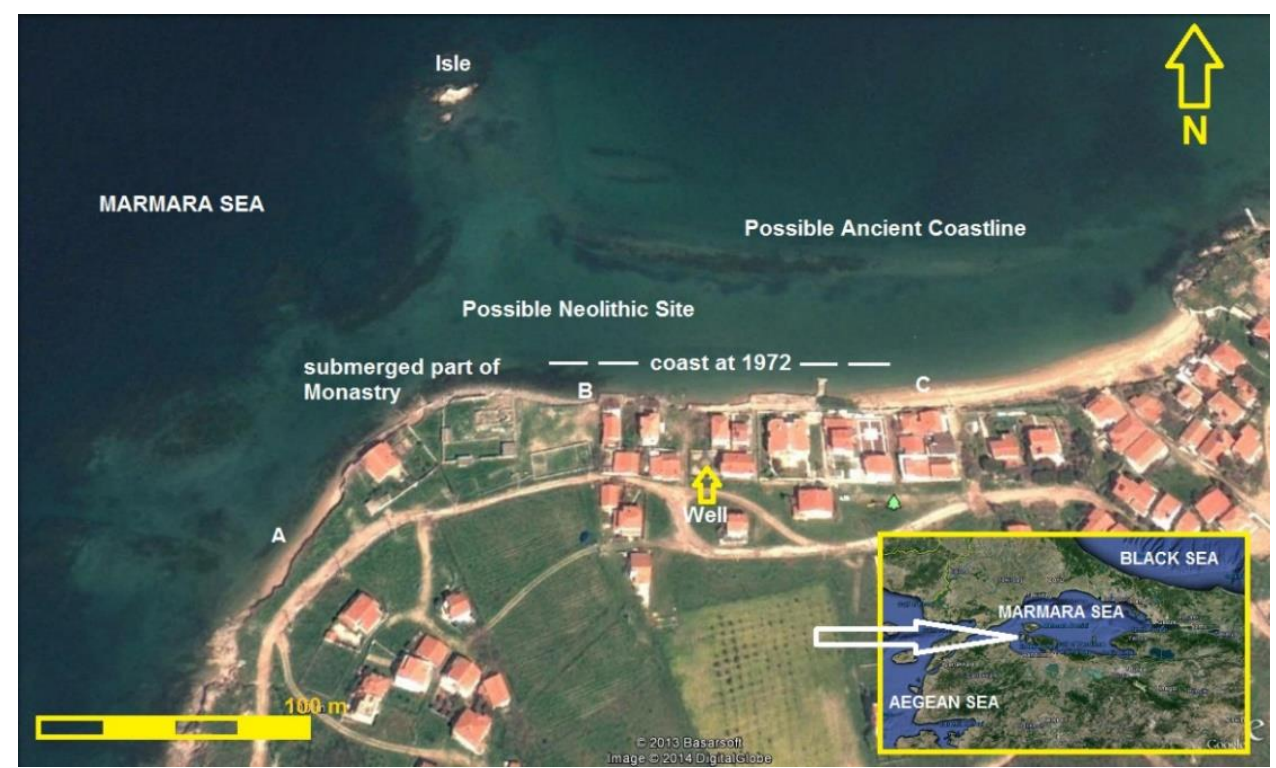

Fig. 9: Possible shoreline and prehistoric settlement in Avşa island (Prepared by Assoc. Dr. Hakan Öniz).

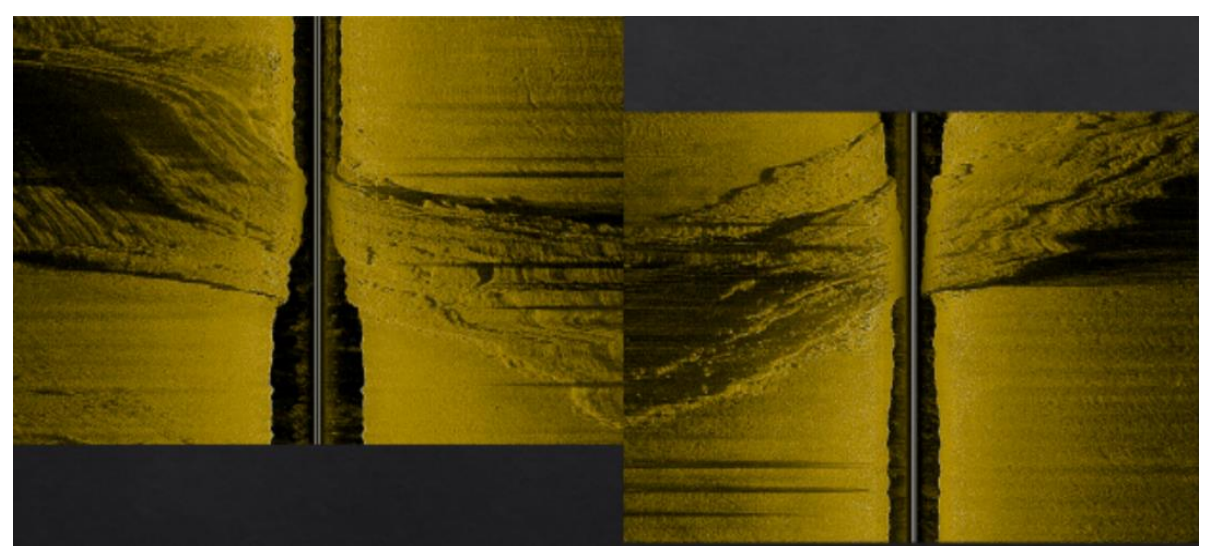

Fig. 10: Possible prehistoric shoreline seen in sonar studies.

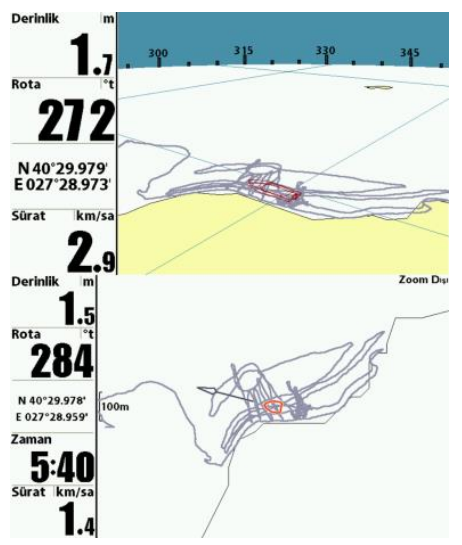

Fig. 11: Avşa Island monastery sonar working areas. 
Diving with mask, fins and snorkel, scuba diving, surface inspection on the shore, sonar study and artifact inspection have been the study methods. These artifacts are the remains that can be observed on the municipal warehouse and on the shore and underwater. First, the mound has been scanned from the surface of the water with mask, fins and snorkel. In this study, the remains that were submerged were examined and the form of the mound and the change of the coastline were tried be understood. Scuba dives have been made in deeper areas. Difficulties have been experienced due to the fact that the ground is partially or completely filled with mussel shells, and in some areas, adequate examinations have not been made. Another working method is studying sonar. An underwater map belonging to monastery region and the area, where mound was located, has been obtained thanks to the side scan sonar studies performed using the boat allocated by Avşa Municipality. During these studies, properly lined stone blocks have been detected by sonar (Fig. 10, 11, 12).



Fig. 12: Stone line seen in underwater.

It is known that obsidians on the coastal line have been used since prehistoric times in the mound's location. These are used especially to make weapons, tools and ornaments in the Neolithic, Chalcolithic and Early Bronze Ages (Fig. 13). It is known that flintstones have been used since prehistoric periods.
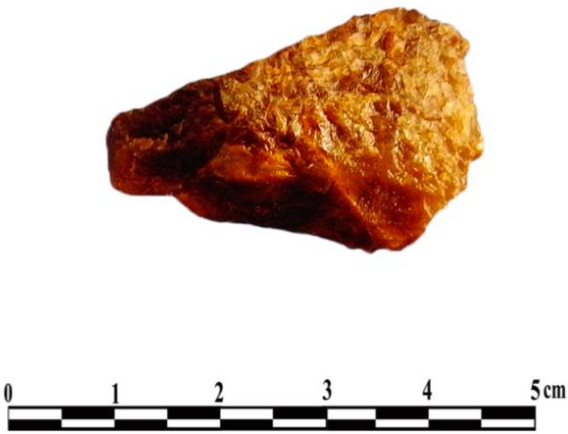

Fig.13: Flintstone found in 2015 Avşa Island Archaeological Research.
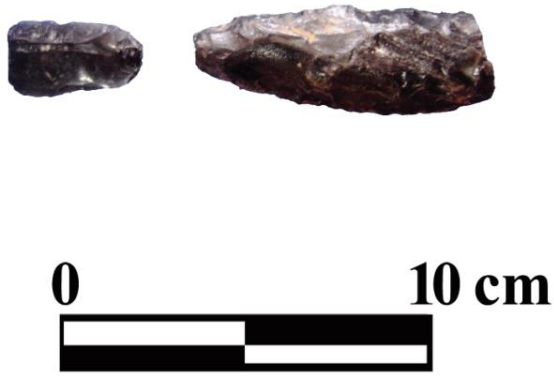

Fig.14: Obsidian arrowhead or spearhead and scrapper tool found in Avşa Island.

These were especially used in the Neolithic, Chalcolithic and Early Bronze Ages, and similar ones have been found in many mounds in Anatolia. During the studies carried out in 2015, obsidian and flintstones (Fig. 14) were documented to be both underwater and on the shoreline. Probably most of these and similar items must have been remained underwater due to the effects of the sea.

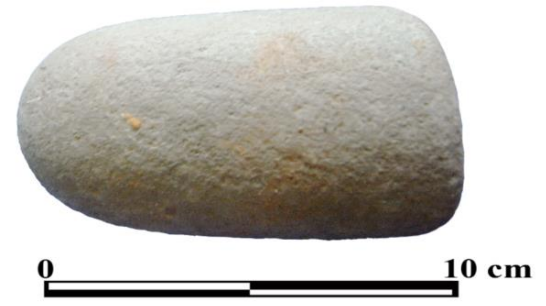

Fig. 15: Stone axe found in Avşa Island.

It is known that stone axes or hand axes had been used as stone tools with two surfaces sculpted in the simplest form since the Paleolithic Period. Although regional differences have been observed in the earliest examples, the most common raw material used had been the flint (Taşkıran, 2001). With the development of technology in the following periods, it continued to be used in the Neolithic, Chalcolithic and Early Bronze Age periods (Özdoğan, 2001). 
A stone axe, which may belong to the Early Bronze Age, has been seen in the municipal warehouse on Avşa Island (Fig. 15).
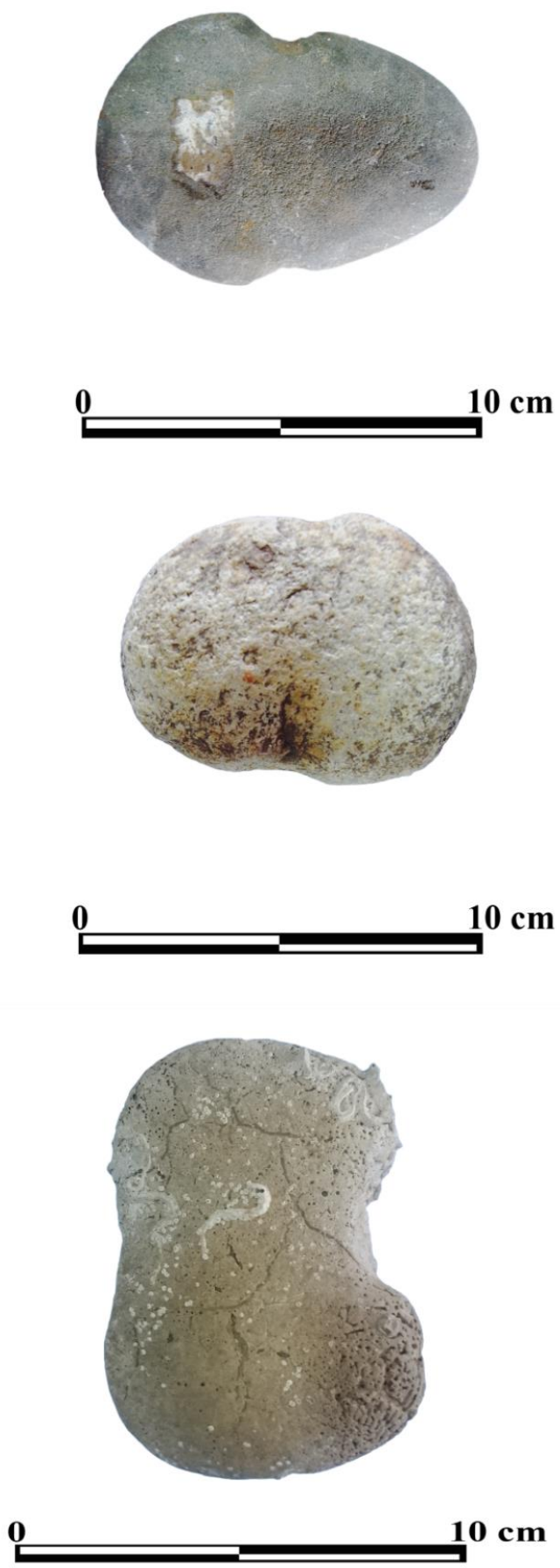

Fig. 16: Idols found in Avşa Island Monastery.

Three figures have also been found in the same warehouse, similar to the "Troya Type" or "8" formed figure samples (Fig. 16). It is known that similar figures were widely used in the Western Anatolian settlements such as Baklatepe and Limantepe; Yortan, Hanaytepe, Kumtepe, Troya in the Early Bronze Age. General features of this type of figures are that they were simply done by schematizing consisting of round head and round or rectangular sack bodies (Y1lmaz, 2013; Aydıngün, 2005; Eroğlu, 2014).

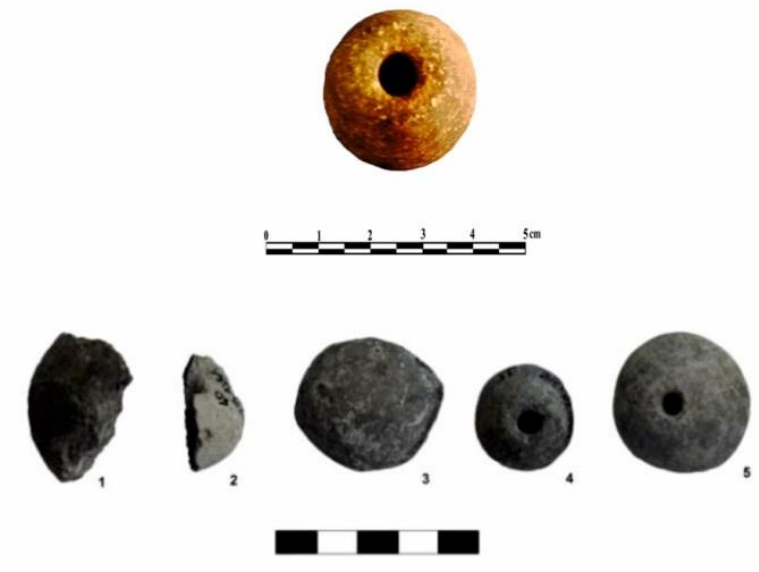

Fig. 17: Loom weight found in Avşa Island

During these studies, a loom weight was found on the coastal form of the mound. The loom weight has a rounded spindle hole, a pit around it, and a convex conical shape at the bottom. The spindle hole is opened vertically. There is no decoration on it. It has been known that this form type was used to a great extent especially in the Early Bronze Age compared to the spindle whorls in Western Anatolia and other regions of Anatolia (Fig. 17).
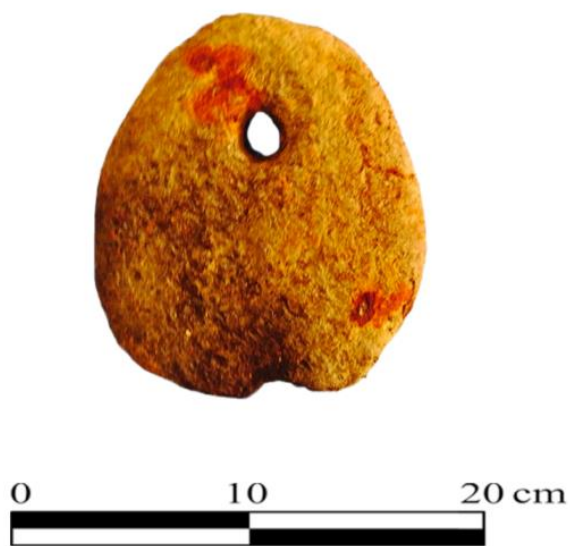

Fig. 18: Weaving weight found in Avşa Island

Among the ruins in the warehouse, there is also a weaving loom weight in the form of a round sphere (Fig. 18). Weaving loom weights ensure that the warp threads remain tight and do not intermingle during weaving (McLauchlin, 1981). It is known that this type of weaving weights has been used since the Late Chalcolithic Period.

\section{Ceramic Finds}

In one of today's settlements in the region, two ceramic pots were found while opening water well near the shore. One of these pots, which were found as a whole, has a polished thickened lip with dark colour. The other one has a form that expands outward. It is dark coloured and polished. This type of potteries can be seen in the Late Chalcolithic and Early Bronze Age in Western Anatolia and Northwest Anatolian Regions (Fig. 19). Another 
ceramic piece that is in the warehouse has been taken out of water and glued by Bandirma Museum officials. The remnant has a dark and polished surface and it is decorated with scraped lines (Fig. 20). It has been known that there are dark colored and decorated pots in the Culture of Fikirtepe. Furthermore, such pots are found in
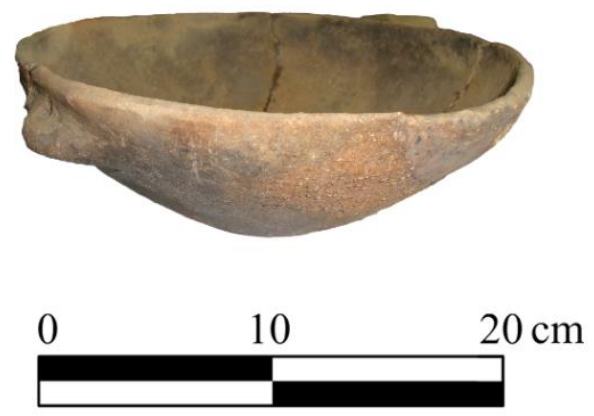

Northern Marmara, Thrace and Balkan cultures. Another possibility is that these ceramic finds may belong to Yortan Culture, which is one of the close surrounding cultures. Yortan Cemetery ceramics are generally date back to the 1st and 2nd periods of Early Bronze Age (Fig. 21).
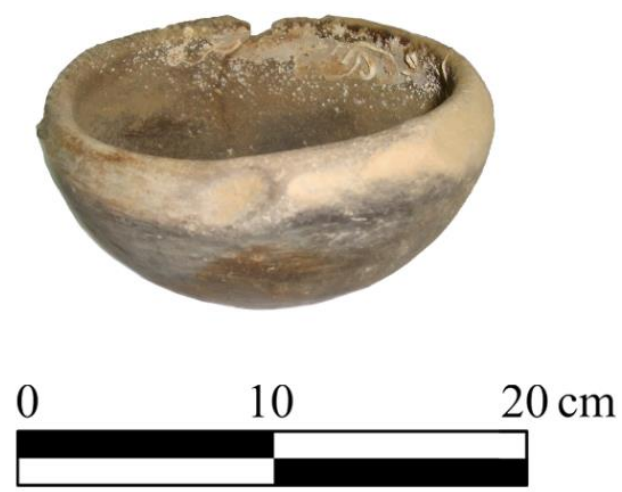

Fig. 19: AA7 (Left) and AA8(Right) numbered wares.
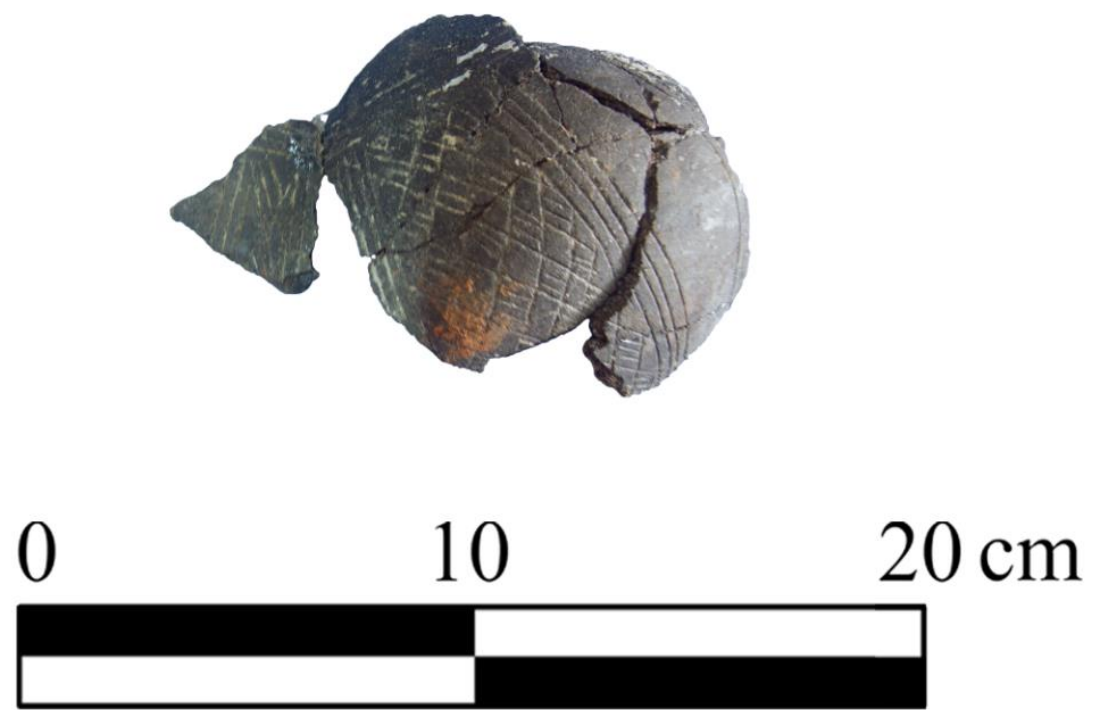

Fig. 20: Sgrafitto ceramic finding found in Avşa Island. Finding no AA9.
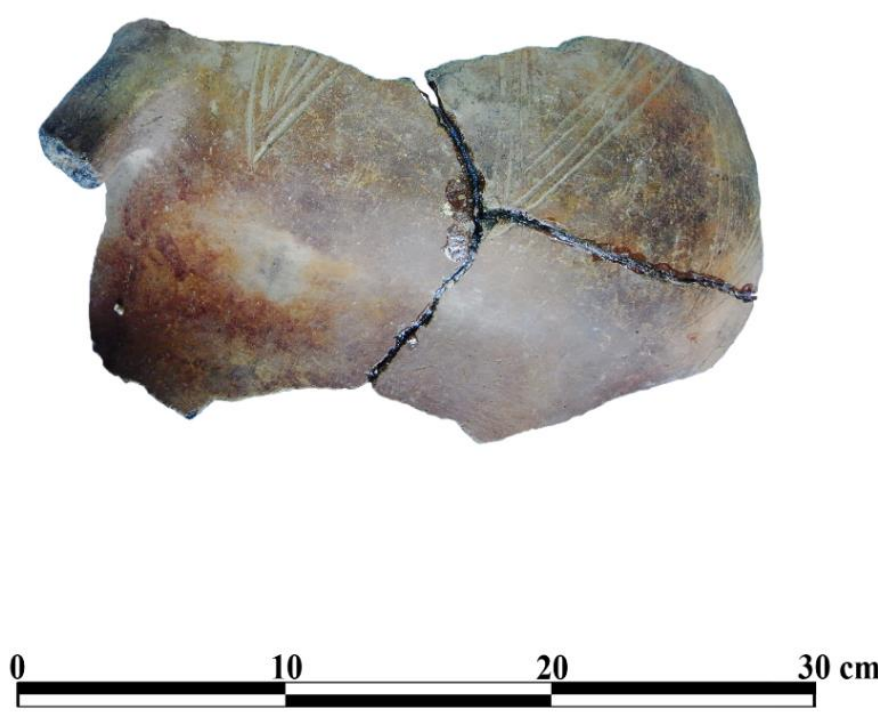

Fig. 21: Sgrafitto ceramic finding found in Avşa Island. Finding no AA10. 
In addition, the handle piece that belongs to the redlined loop-handled cup that is located underwater during studies is especially dated to the Early Bronze Age II in Western Anatolia (Fig. 22). Another ceramic remnant in the warehouse has a volute-shaped handle and it is light buff colored. As it has the same properties with ceramic samples from the period corresponding to the Troy V layer, it can be said that these periods are contemporary. There are pithos tombs among the most important remnants seen underwater in Avşa Island (Fig. 23, 24, 25).


Fig. 22: Knot handled ceramic finding in Avşa Island.

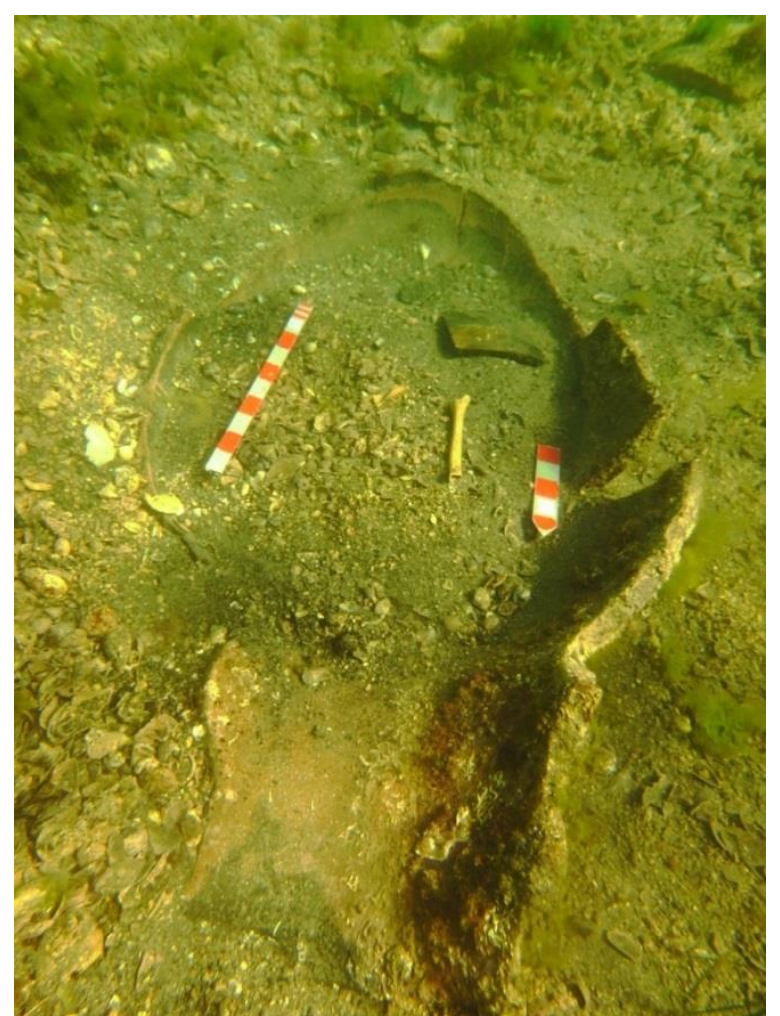

Fig. 23: Submerged pithos grave dated to Early Bronze Age in Avşa Island.

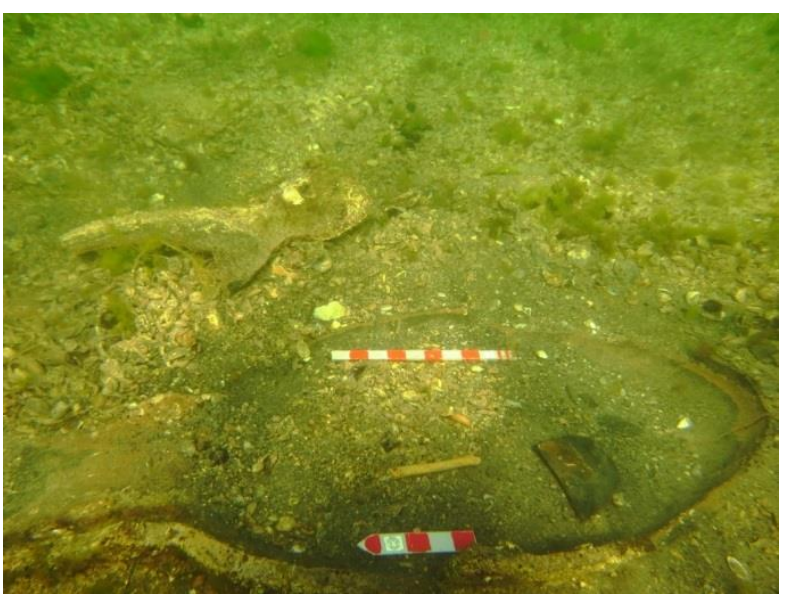

Fig. 24: Submerged pithos grave dated to Early Bronze Age in Avşa Island.

Pithos graves are one of the methods frequently used as burial methods in the Early Bronze Age. Although the forms of pithos used vary, they are usually necked with 2 or 4 handles, flat or pointed bottomed, and wide mouthed (Uhri, 2006). The mouths of pithos graves are usually closed. Large sizes of stones or ceramic pots have been used to cover the mouths.

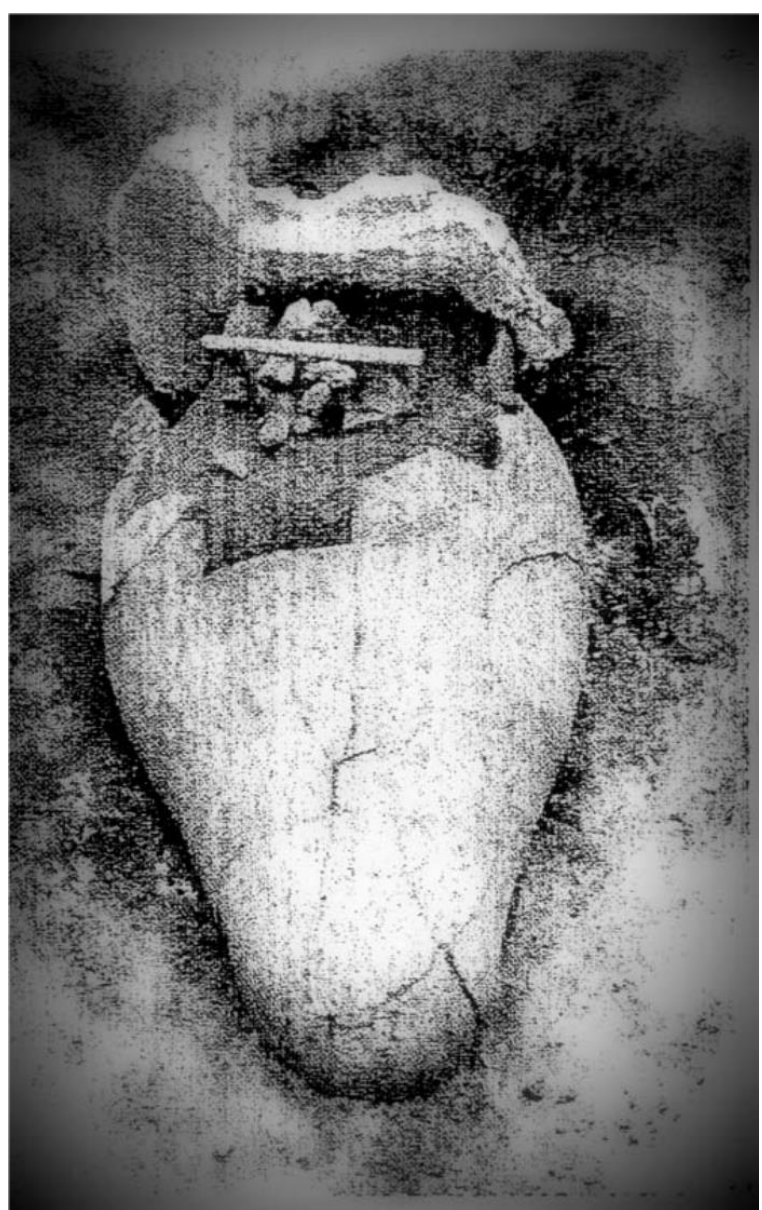

Fig. 25: Pithos Grave sample found in Balıkesir - Babaköy (Özgüç, 1948, Fig. 25). 
It can be assumed that mouths have been deliberately left open or the material used to cover the mouth has disappeared from the mouths of the graves which were captured open. Some of the pithos tombs in dating back to the Early Bronze Age are located in Ahlatl Tepecik (Mitten and Yükrüm, 1969), in Aphorodisias (Joukowsky, 1986), in Bakla Tepe (Özkan and Erkanal, 1999), in Harmanören (Özsait, 1995), in Küçükhöyük (Gürkan and Seeher, 1991) and Ulucak Höyük (Çilingiroğlu et al., 2004; Derin and Özkan, 1999) in Western Anatolia.

Pithos tombs in Avşa Islandwere found approximately 5 meters from the shore and at a depth of 2.50 meters. The tomb, thought to belong to the Early Bronze Age, is partially closed due to dense mussel shells. The upper part of Pithos is largely broken, but the lower part has been found intact. Bone fragments and amorphous ceramic pieces in the pithos remain in situ. These underwater remains in the region are at risk by natural and human influence and should be taken under protection.

\section{Results}

With its location in the northwest of Anatolia, the Marmara Region is of great importance in that it has three shores and a connection point between the two strait and the continents. The sea connections provided an advantage to Marmara Region in terms of establishing relations with an extensive geography. Besides, the richness of the region in terms of various natural resources increases its attractiveness. Owing to the underwater researches carried out in the region, many wrecks have been identified so far and the sea culture history of Marmara will be enlightened of these findings. Numerous prehistoric settlements, which have been inundated by the effects starting from the Holocene Period, are waiting to be discovered over the world. The studies on this field just the tip of the iceberg.

\section{Acknowledgements}

We would like to thank primarily to the Ministry of Culture and Tourism, for issuing our work permits, and to the General Directorate of Cultural Heritage and Museums for their support during this time, and to Bandırma Museum Directorate and Avşa Island Municipality.

\section{Bibliography*}

Algan, O., Yalçın, M., Özdoğan, M., Yılmaz, Y., Sarı, E., Kırc1-Elmas, E., Yılmaz, İ., Bulkan, Ö., Ongan, D., Gazioğlu, C., Nazik, A., Polat, MA. \& Meriç, E. (2011). Holocene coastal change in the ancient harbor of Yenikap1-İstanbul and its impact on cultural history. Quaternary Research, 76(1), 30-45. doi:10.1016/j.yqres.2011.04.002.

Algan, O., Yalçın, M.N., Yilmaz, Y., Perincek, D., Özdogan, M., Yilmaz, I., Meric, E., Sari, E., Kirci
Elmas, E., Ongan D., Bulkan Yesildali, O., Danisman, G., Ozbal, H., (2007). Gün Işı̆̆ında İstanbul'un Sekizbin Y1l. Marmaray, Metro ve Sultanahmet Kazıları. Antik Theodosius Yenikapı Limanı'nın Jeoarkeolojik Önemi: Geç Holosen Ortam Değişimleri ve İstanbul'un son 10 bin yıllık Kültürel Tarihi (Ed. Kiziltan, Z.) Vehbi Koc Yayinlari, İstanbul, 242-245.

Algan, O., Yücel, Y., Yalçın, N., Özdoğan, M., Sarı, E., Kirci-Elmas, E., Yilmaz, I., Bulkan, Ö., Ongan, D., Gazioğlu, C. (2010). Geo-Archaeology Of The Ancient Theodosius Harbour (Yenikapi-Istanbul): Implications To Holocene Sea Level And Coastal Changes, 2010 Gsa Denver Annual Meeting.

Ardel A. ve Kurtel A., (1973). Marmara Denizi. Ístanbul Üniversitesi Coğrafya Enstitüsü Dergisi, Say1: 18-19, 57-70.

Ardel, A., (1960). Marmara Bölgesinin Yap1 ve Reliefi. Türk Coğrafya Dergisi, Sayı: 20, 1-2.

Aslan R., (2011). 2011 Y1lı Bozköy-Hanaytepe ve Çevresi Prehistorik Dönem Yüzey Araştırması. 30. AST, Cilt 1, T.C. Kültür ve Turizm Bakanlı̆̆ Kültür Varlıklarl ve Müzeler Genel Müdürlüğ̈̈ Yayın No:157-1, 5-18.

Aydıngün Ş., (2005). Tunç Çă̆ı'nın Gizemli Kadınları / Mysterious Women of Bronze Age. Yap1 Kredi Yayınları Kültür Sanat Yayıncılık, İstanbul.

Aydıngün Ş., Heyd V., Gündoğan E., Öniz H., (2014). İstanbul'un Batısında Kalan Son Höyük: Selimpaşa. Engin Özgen'e Armağan Kitabl, Ed. Engin A., Helwing B. ve Uysal B., Asitan Kitap, Ankara, 4555.

Basaran, S., (2008). Iron Ways" and an Ancient Harbor on the Marmara Coast, the "Old Ships" of the "New Gate" 1. Yenikapi Shipwreck, Volume 1, İstanbul, 122.

Basgelen, N., (2013). Istanbul'da marmaray-Metro Projeleri Kurtarma Kazıları (2004-2011) ve Kent Arkeolojisine Katk1lar1. Journal of Archaeology and Art, Istanbul, 113-124.

Burroughs W. J., (2005). Climate Change in Prehistory: The End of the Reign of Chaos. Cambridge University Press, Cambridge, 45.

Çilingiroğlu A., Polat G., Mercangöz Z., (2012). Ulucak Höyüğ̈̈’, Ege Üniversitesi Arkeoloji Kazlları, 2012, 158-168.

Dönmez Ş., (2006). The Prehistory of the Istanbul Region: A Survey. ANES 43, 239-234.

Dumankaya, O. (2015). Koyunbaba Ancient Stone Quarry Dock. International Journal of Environment and Geoinformatics, 2(3), 40-47, doi. 10.30897/ijegeo.303561.

Erkanal H., Şahoğlu V., Tuğcu İ., (2014). Liman Tepe / Klazomenai Liman Kazıları. TINA Denizcilik Arkeolojisi Dergisi, Say1: 1, 11.

Eroğlu G., (2014). Neolitik Dönem'den Erken Tunç Çağ1 Sonuna Kadar Batı Anadolu'da İnsan Figürinleri ve Çevre Kültürleriyle Olan İlişkileri. Ege Üniversitesi Sosyal Bilimler Enstitüsü, Yayımlanmamış Doktora Tezi.

Erol O., (1979). Dördüncü Çağ Jeoloji ve Jeomorfolojisinin Ana Çizgileri. DTCF Yayınları, Ankara. 
Eshed ve Galili, (2011). Palaeodemography of Southern Levantine Pre-Pottery Neolithic Populations: Regional and Temporal Perspectives. (Editors Ron Pinhasi and Jay T.Stock). Human Bioarchaeology of the Transition to Agriculture. West Sussex: WileyBlackwell, 403-428.

Günsenin N., (1995). 1994 Yılı Marmara Adaları Sualtı Araştırması. XIII. Araştırma Sonuçları Toplantısı 1. Cilt, Türkiye Cumhuriyeti Kültür Bakanlı̆̆l Anıtlar ve Müzeler Genel Müdürlüğü, Yayın No: 1809, Ankara, 357-374.

Gürkan G. ve Seeher J., (1991). Die Frühbronzezeitliche Nekropole von Küçükhöyük bei Bozüyük. Istanbuler Mitteilungen, Say1: 41, 39-90.

Henderson J.C., Gallou C., Flemming N.C., Spondylis E., (2011). The Pavlopetri Underwater Archaeology Project: Investigating an Ancient Submerged Town. Submerged Prehistory, Oxbow Books, 207-218. (Ayr1 Basım)

Jordan W.J. Maschner G.D.H., (2000). Coastal Paleogeography and Human Occupation of the Western Alaska Peninsula", Geoarchaeology: An International Journal, 15 (5), 385-414

Joukowsky M. S., (1986). Prehistoric Aphrodisias I-II. D'Histoire De L'Art et D'Archéologie De L'Université Catholique De Louvain, XXXIX, Louvain - Belçika

Karul, N., (2011). The Emergence of Neolithic Life in South and East Marmara Region, Beginings - New Research in the Appearance of the Neolithic Between Northwest Anatolia and the Carpathian Basin Papers of the International Workshop $8^{\text {th }}-9^{\text {th }}$ April 2009 (Ed. Kraub, R.), Rahden/Westf: Leidorf ,57-65.

Kayan İ., (1997). İznik Gölü batısındaki Ilıpınar Höyüğü çevresinde jeomorfolojik ve jeo-arkeolojik araştırmalar. Ege Coğrafya Dergisi, 9, 47.

Kayan İ., (2019). Anadolu'nun Ege Kiyılarında Holosen Deniz Seviyesi Değişmeleri ve Jeoarkeolojik Etkileri. TINA Denizcilik Arkeolojisi Dergisi, 12, 11-35.

Kiziltan, Z., (2008). Foreword, Istanbul Archaeological Museums Proceedings of the 1st Symposium on Marmaray-Metro Salvage Excavation. İstanbul.

Kocabas, U., (2008). Istanbul University Yenikapi Shipwrecks Project: The Ships. Istanbul Archaeological Museums Proceedings of the 1st Symposium on Marmaray-Metro Salvage Excavation. İstanbul, 23-33.

Marinova M.F., Giosan L., Angelova H., Preisinger A., Pavlov D, Vergiev S.(2011). Palaeocology of Submerged Prehistoric Settlements in Sozopol Harbour, Bulgaria. Submerged Prehistory.

McLauchlin B. K., (1981). New Evidence on the Mechanics of Loom Weights. American Journal of Archaeology, 85 (1), 1981, 79-81.

Mitten D.G. Yüğrüm G., (1969). Excavation at Ahlatlı Tepecik the Gygean Lake - 1968. TAD, XVII-1, 1969, 125-131.

Öniz, H., Kaya, H., Gazioğlu, C. (2015). Geoarchaeological Researches on the Mediterranean Coast, II. Klyı ve Deniz Jeolojisi Sempozyumu, 133.

Özdoğan M., (2000). Kırklareli Kazıları: Aşağıpınar ve Kanlıgeçit. O. Belli (ed.), Türkiye Arkeolojisi ve İstanbul Üniversitesi (1932-1999), Ankara, 69-76.
Özdoğan M., (2000). The Bronze Age in Thrace in Relation to the Emergence of Complex Societies in Anatolia and in the Balkans. $\ddot{U}$. Yalçın (Ed.), Anatolian Metal II, Bochum: Deutsches Bergbau Museum, 67-76.

Özdoğan M., (2007). Marmara Bölgesi Neoloitik Çağ Kültürleri, Türkiye'de Neolitik Dönem: Anadolu'da Uygarlığın Doğuşu ve Avrupa'ya Yayılımı Yeni Kazılar, Yeni Bulgular. Ed: M. Özdoğan, N. Başgelen, Arkeoloji ve Sanat Yayınlart, İstanbul, 401-426.

Özdoğan, M., (2003). The Black Sea, the Sea of Marmara and Bronze Age Archaeology - an archaeological predicament. In Wagner, G. A., Pernicka, E. and Uerpmann, H.-P. (eds) Troia and the Troad. Scientifi c Approaches. Berlin, Springer, $105-120$.

Özdoğan, M., (2011b). Eastern Thrace: the Contact Zone between Anatolia and the Balkans. Oxford Handbook of Anatolia. (Eds. Steadman, S.R., McKahon, G), Oxford University Press, Oxford, 657-682.

Özgüç T. (1948). Ön Tarihte Anadolu'da Ölü Gömme Adetleri. Türk Tarih Kurumu Basımevi, 7 (17), Ankara.

Özkan T. Erkanal H., (1999). Tahtalı Barajı Kurtarma Kazısı Projesi / Tahtalı Dam Area Salvage Project. İzmir Arkeoloji Müzesi Müdürlüğü Yayınlarl, İzmir.

Özsait M., (1995). 1993 Yllı Harmanören Mezarlık Kazısı. XVI. Kazı Sonuçları Toplantısı, II, 153-174.

Pekin, A. K., (2007), Gün Işığında İstanbul'un 8000 Y1lı: Marmaray, Metro, Sultanahmet Kazlları, Vehbi Koç Vakfi Yayınları, İstanbul

Perincek, D., (2008). Geoarchaeology of the Excavation Site for the last 8000 Years and Traces of Natural Catastrophes in the Geological Profile. İstanbul Archaeological Museums Proceedings of the 1st Symposium on Marmaray-Metro Salvage Excavation. Istanbul, 191-218.

Runnels C. ve Özdoğan M., (2001). The Paleolithic, of the Bosphorus region. NW Turkey, Journal of Field Archaelogy, 28, 69-92.

Taşkıran H., (2002). El Baltalarl. Arkeoatlas Dergisi, İstanbul, 53.

Uhri A., (2006). Batı Anadolu Erken Tunç Çağı Ölü Gömme Gelenekleri. Ege Üniversitesi Sosyal Bilimler Enstitüsü, Yayımlanmamış Doktora Tezi, İzmir.

Van Andel T., (2005). Coastal migrants in a changing World? - An essay on the Mesolithic in the eastern Mediterranean. Journal of The Israel Prehistoric Society, 35, 381-396.

Yılmaz D., (2013). Doğu Ege'de Yeni Bir Erken Tunç Çağı Kenti: Troas Bölgesi'nde Bozköy-Hanaytepe Yüzey Araştırmaları. The Journal of Academic Social Science Studies, 6, 857-888. 